\title{
Experiencing the corona effect in the city square through Lefebvre's spatial trialectic: the case of Afyonkarahisar
}

\author{
Şerife Ebru Okuyucu' ${ }^{1}$. Gamze Çoban ${ }^{1}$ (1)
}

Received: 25 May 2021 / Accepted: 19 July 2021 / Published online: 4 August 2021

(c) King Abdulaziz City for Science and Technology 2021

\begin{abstract}
The aim of the study is to filter the behavioural and spatial practices of subjects who experience/practice the square with respect to Lefebvre's trialectic space approach and place them to an analytic plane in the context of reading the dynamics in the city square of Afyonkarahisar during the corona days when decisions and prohibitions taken by the government are applied. The article is an experimental study and important data regarding the space-oriented practices and dynamics in Afyonkarahisar city square during the corona days have been obtained by adopting monitoring/observing and experiencing methods and reading the theoretical and conceptual framework of Lefebvre's spatial approach theory related to the literature review. Images, actions, government policies and behavioural patterns of people in the square on the determined important dates have been accepted as empirical findings of the field study. Findings that have been obtained have been read again through subjects who experience/practice Afyonkarahisar urban square during the coronavirus pandemic in the context of Lefebvre's trialectic space approach.
\end{abstract}

Keywords Coronavirus $\cdot$ Lefebvre $\cdot$ Trialectic space approach $\cdot$ Afyonkarahisar $\cdot$ City square

\section{Introduction}

"the city is the space of change, metamorphosis, plurality, the cradle of civilization; therefore, it is the point where many material and spiritual values that form the utopian or realistic aspirations of most people emerge, improve and cradle of civilization. From a point of view, "city" means "square". The fact that every city is a "respublica", that is, a public object and the partnership, in which the inhabitants create the awareness of forming a "corpus" (body), necessitate the existence of the spaces. The square is the urban space caused by such a necessity...." (Calvino 2016).

Cities are spaces that accommodate many people at different levels culturally, socially and economically. A social

Şerife Ebru Okuyucu

ebruokuyucu@hotmail.com

Gamze Çoban

a.gamzecoban@hotmail.com

1 Department of Interior Architecture and Environmental Design, Fine Arts Faculty, Afyon Kocatepe University, ANS Campus, 03200 Afyonkarahisar, Turkey communication is aimed by ensuring that these people, who have different centers, come together in a common center, that is, in the "city squares," even if they have different purposes (Moughtin 2003). According to Uçak, squares are defined as the areas where social changes occur, reflecting the culture, beliefs and values of the society in which it takes place (Çaçtaş, 2016). Lynch (2016) emphasized that city squares are the focus of intense activities created in urban spaces. According to Küçükerbaş ve Özkan (2003), the square, which is a large open space that serves the urban people as a place to gather by starting and guiding the urban circulation creates a perception of space that also provides the opportunity to stop and does not force mobility rather than a directed movement order.

The square is space in which people stay more; it is not just an area where people come and go like roads and streets. Since it is the place where people come together, it has a gathering feature with its center or centers. While perceiving their environment, people take themselves as the centre, this perception in their mental schemes requires a reference point in the outside world and seek continuity between their inner centers and this outer center. The physical definitions of these centers in each culture, architecture and urban order are different (Alexander 1977). 
In order for squares to become an important part of the city and to be spatialized; they should change, develop and create their own dynamics. As Tschumi states existence of the space depends on the existence of a practice. "If there is no action, there is no space." (Tschumi 1996).

In this context, a communication should be established between the square-space-subject and the squares should undertake the dynamics of the city in order for the squares to become part of the city and spatialize. City squares are perceived as the absolute fortress of the change and movement in the cities. According to Lefebvre (2014), the urban space (squares) is experienced by the city subject. The subject of the city relates different times and different places in the city. As the relationality of this place (square); space (square) and subject are no longer opposed forces but rather turn into a dialogical process of common life and this process is generally experienced by establishing intensive relations between square-subject-society-city.

However, there are times when the practice of the dialogical relationship of the city squares with the city dwellers diminishes and disappears in the historical process. Wars or pandemics occur in cities, countries and sometimes all over the world that negatively affect human health, social life, economy and social dynamics. In this study which deals with the experience of how pandemics affect cities and urban spaces through the square, the effect of coronavirus spread on the social life of people in the process, which has been affecting the whole world recently and declared as a pandemic by the World Health Organization, has been taken as reference. Within the framework of this study, reading the impact of coronavirus pandemic which has been taken as the reference on dialogic relationship of space and subject of Afyonkarahisar city square and their square-focused practices with an experimental approach has been conducted within the context of Lefebvre's trialectic space analysis. These readings which constitute the main frame of the study are based on the trialectic space approach developed by Lefebvre regarding how cities and city squares are given meanings, designed and experienced consisting of spatial practice, representation of the space and space of the representation.

The sociological effect of the coronavirus which is called pandemic on the urban space scale is perceived by measuring the usage potential and space practices of squares that constitute the elements of the cities when the social processes are observed. In this context, as a document containing important data on space-oriented practices and dynamics in the city square of Afyonkarahisar, the human population in the square was examined on important dates when the coronavirus epidemic was effective in the social and physical context of the city. Numerical data about the population of the square were taken from Afyonkarahisar Municipality. Images, actions, government policies and behavioural patterns of people in the square on the determined important dates have been accepted as empirical findings of the field study. Findings that have been obtained have been filtered through Lefebvre's trialectic space approach and placed on an analytic plane. A guideline model has been prepared to reread the city square of Afyonkarahisar through subjects who experience/practice the square during the coronavirus pandemic with respect to analytical framework of theoretical trialectic space concept of Lefebvre (Fig. 1).

\section{Urban space-square-society}

"Beyond being an object which can be perceived and even enjoyed by millions of people with a wide variety of classes and characters, the city is also the product of many creators who constantly improve its structure for their own reasons. Although it remains generally stable for a while, its details constantly change. Only a partial control over its growth and form can be achieved."' (Lynch 2016).

Based on this definition of Lynch, it is concluded that the city, the city spaces and, therefore, the squares that are part of the city are spaces which are alive, changing, developing and building relationship with the urban dwellers. Urban spaces and squares are places where urban communication and togetherness are provided. To understand the level of the relationship between the urban dwellers that constitute the structure of the city, urban spaces and urban squares and the spatial effect on society, it is necessary to take a look at the urban space with a holistic approach with respect to the relations between subject, space, time and life dimensions. It is seen that cities and city centers change the social and spatial usage practices and according to Erdönmez and Ak1 (2005), city squares are extremely effective on social

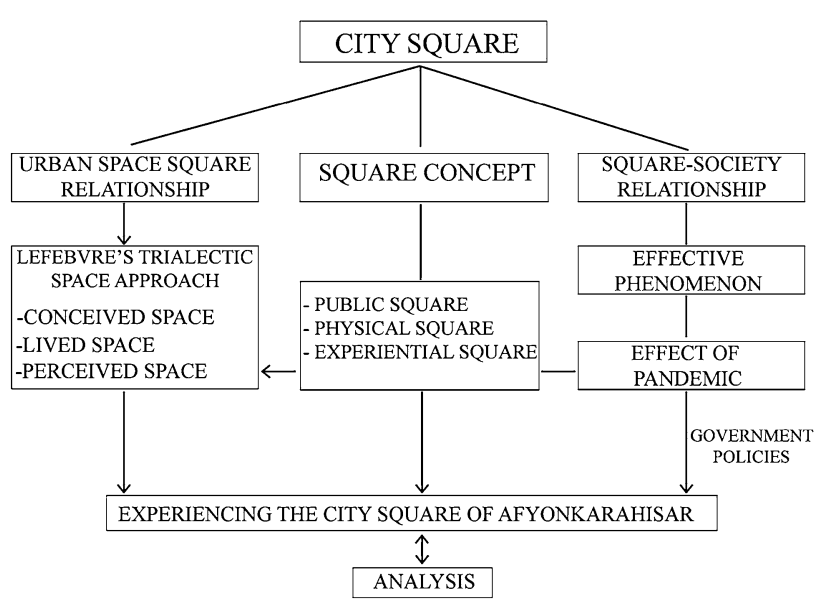

Fig. 1 Model prepared for experiencing Afyonkarahisar city square 
life. Space and human interaction directly contributes to the dimension of human behavioural relations in space and determining the living conditions and the usage practices of space. Space-human interaction reveals the degree of urbanization (Erdönmez and Akı 2005). (Taksim Square) These areas bringing the society together are urban squares, public communication squares, focal points and arenas. These are the areas that make human interaction possible. Accordingly, city squares are of great importance in terms of strengthening social awareness for the society. There are basic sociocultural and psychological elements that need to be addressed in community-space interaction. These are how people choose these areas, what they do in these areas and what kinds of interactions they have and how they carry out their activities in these areas and these are the main issues to be addressed (Erdönmez and Ak1 2005).

In the historical process, Pol (2002), urban squares have been defined as the areas where individuals and communities can stay together and socialize in the context of its place and location on the city scale. According to Akpınar and Gümüs (2012), the level of the relationship of the squares that are part of the city planning with the society and the city is an indicator of the functional, physical and social usefulness of the squares. The opportunities offered by the city square to the city dwellers can be addressed within the framework of meeting the collective, cultural, political and social life needs.

Marcus and Francis (1998) define today's squares as a community square in general. As a result of this transformation of spatial perception, social relations and cultural relations of the society, which we cannot think separately from each other, have gained importance and usage practices associated with perception of space have come to the fore.

According to Lefebvre (2015), the space is primarily understood as a social product in the in the production of space. However, this product is not an ordinary product or object but a definition that includes production, product and their in-depth relationships. The concept of space connects mental and cultural as well as social and historical. Stavrides $(2016,2018)$, at the same time, urban squares which form a complex process can be defined as the places where the societies continue their lives and activities and where they live their sociocultural life. According to Erdönmez and Ak1 (2005), healthy structuring of the society takes place in the city squares which are the spaces where the relationship between individuals and society is supported by the physical environment.

Each implicit or explicit struggle for re-establishing the space constantly (the practice of the city planner-the practice of the subjects in everyday life); in other words, deconstruction or displacement indicates a process that explicitly refers to rearranging the spatial foundations and structure of this relationship (urban space-urban subject). In this context, the city, urban space and urban square become analysable as a process. The main dynamics of this process are the space production and trialectic space approach which Lefebvre considers a phenomenon not only with geographical and physical meanings but also with social and political meanings and functions. This point of view was made possible by analysing the relationships that people build with spaces, social phenomenon and the government. Indeed, seeing space as a social product also allows us to analyse the relations of production and reproduction at the root of this sociality (Lefebvre 2015). In other words, according to Keleş (2012), it should be accepted that city square is not only a geographical or topographical concept but rather it is a concept of which discourse and action functions predominate Keleş (2012), emphasize that the important phenomenon in urban squares is "sociality".

The reading of the dynamics, practices, meanings and codes formed in the context of the relationship of urban spaces with the urban subject and society can be done through dialectical or trialectic space approaches that space theorists experience through cities. In the definition of space of theorists such as Henry Lefebvre (2015), Sodja (1996), Foucault (2016), Deleuse (2013), the emphasis on the place lived (city squares) grabs attention.

\section{Reading the city square through Lefebvre's space trialectics}

What is space (urban space)? Is it a 'place' in which people stay or move? Or is it an empty plane? Is it stationary and passive or dynamic and active? Or with the question of Lefebvre; "Is the space (urban space) a passive social relationship place, a stabilized unification environment of these relations or is the sum of the methods of maintaining relations? (Lefebvre 2014). Space, thus, the urban space is a controversial concept; it is neither an empty surface nor stationary. It has characteristics that include dynamism. Lefebvre offering the possibility of a perspective based on the communication between space and society and the subject by liberating the space from the hands of the Cartesian philosophy which attributes a self-styled symbolism to the space and Euclidean geometry does not define the space as an empty container where activities occur on/in the space; on the contrary, considers the space as a process/ formation, which is produced, constantly produced, transformed, and Harvey (2013), redefined by social practices through a situation which is actively drawn/designed from above and controlled, built and controls the subjects within it. According to Lefebvre (2015), the space is based on the language/narration/story/experience and practice included in daily life and can be connected with synchronicity. The relationship between the urban space and the urban subject

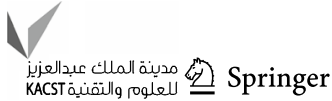


dialogically manifests within this respect in the form of a kind of political spatial domination/setting and displacing this spatial domination/setting/deconstruction and criticize tension. The regime on which this dialogical relationship is based between the urban space and the urban subject lies in the relationality between design/setting and experience/ practice. Lefebvre's scheme has been placed in physical, discursive and symbolic features of the urban space and the spatial experience of the subjects and spatial practices based on the dialogic relationship regarding the urban space. "The city is not only a language but also a practice." The only place where the city itself and the spatial and social relations and processes of the city can be given a meaning in an integrated framework is the daily life as the space of the subject's spatial practices and experiences." Stanek (2011), because daily life is a place where space is produced and experienced. According to Stanek (2012), the main feature of daily life is that it is an area where the space is repeatedly produced. In the production process of space in daily life, Mumford (2013), the relation of capitalist capital/government/ruling authority and relationship of the subject with space takes its place as the main determinant. The subject's use of space in everyday life also corresponds to a production, or the subject that experiences the space in daily life reproduces the same space (by himself). The subject, who uses the opportunity created by the contradictions in the structure of the abstract space in daily life, constantly takes a role in the production and reproduction of the social space (Diology of space). Lefebvre, draws attention to involvement of the subjects who experience/practice the urban space by reinterpreting the space against the spatial thought controlling/regulating the urban space and carefully examines the space in terms of government, control and more specifically subject and urban space (Lefebvre 2015).

In the model of Lefebvre (2015), space (urban space) is a theory of definition in a broad framework with an arrangement, society and its dynamics. (Lefebvre 2015). In this context, readability of space (urban space) is important. Although communication tools such as messages, codes and information do not provide the following of the birth of the space, the space decodes itself and it is read according to Lefebvre (2015). Wherever there is space, there is existence.

In this context, based on Gülhan's (2013) interpretation which defines space as the place of mind and life, the production process of the city square, which is one of the city spaces, is handled by Lefebvre with a trialectic perspective in the form of a social space with three moments that have dialectical relationship in themselves. Based on the Lefebvre's idea regarding space (2014) that the space is political, has an economic value that can be bought and sold and that individual productions shape the space, it is possible to perceive the city squares as places that are produced and experienced and where cultural activities, social events, rallies, political and union activities, sports activities and trade functions take place.

Lefebvre tries to form the holistic spatial theory with a spatial triad, trialectic spatial approach without getting stuck in binary oppositions (Schmid 2008). In this context, Lefebvre (2014) defined social space as a dynamic phenomenon and space production as perceived space (spatial practices), conceived space (representations of space) and lived space (space of representations) in his conceptualized space trialectic. The spatial triad which Lefebvre calls "spatial triad", that is "perceived space" which we live directly without questioning and shapes our space-oriented practices, habits, "conceived space" which shapes the space design, its theoretical and abstract concepts, planning and setting space and "lived space" which is contradictory, fundamentalist, revolutionary and carries the art, uncertainty and irrational that interrupts the routine is not a only a dialectical formation, but a "trialectic" that presents the unique rhythm of this triad together (Lefebvre 2015). In the study, the theoretical infrastructure of Lefebvre's trialectic space approach is tried to be analysed with a comprehensive model by overlapping with the components defined for the experience of the city square. In (Fig. 2), the representational model of the space production that Lefebvre textually conceptualized.

\section{Representations of space (conceived space)}

These are practical and informational forms that organize and represent space. The conceived space corresponds to the conceptual space created by professionals and technocrats and is the dominant space in a society. Jargon, indicator, codification, objectified representations are produced and used by these agents and actors. In the conceived space, visual relations are dominant and power, ideology and knowledge are embedded in these images without exception. According to Lefebvre, this space is the space of capital and is the most dominant type of space in any society. Representations suck as architectural plans, city maps, metro maps, number speculations such as the golden ratio, googleearth, etc. can be given as examples (Lefebvre 2014). Spatial representations reflect this information and ideology in their spatial textures through effective information and ideology;

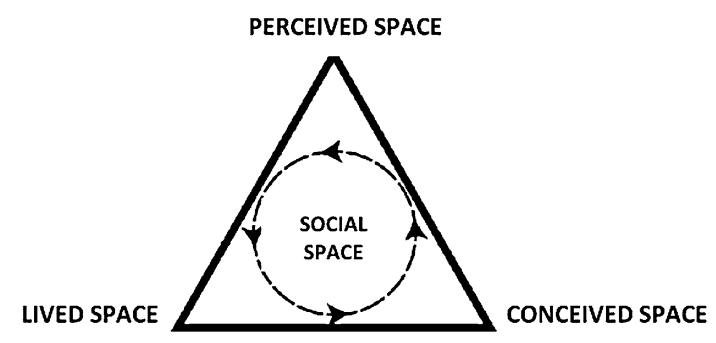

Fig. 2 Lefebvre's perceived-conceived-lived triad and social space 
therefore, "spatial representations have an important scope and specific effect in spatial production" (Lefebvre 2015). This space made of mentally thought 'conceived' and objectified plans, icons, etc. contains abstraction. Therefore, the representation space is also defined as the conceived space. Space representations cannot be separated from spatial practices and spatial experiences which are associated with it due to its scope and importance to physical texture. It has a close relationship. If a general concretion is made, the division of the space into zones, the plotting, inclusion of the space in a division of work and specialization, division or combination of functions, people and things in the space can be given as examples of the representation of space.

\section{Space of representations (lived space)}

They are the spaces of daily life. They include symbolic differences and collective fantasies about space. The lived space is experienced through complex symbols and the images of its users and covers the physical space. It is an effective center: square, church, house, bed, cemetery, etc. It is more emotion than thought. The lived space is an experimental region in which the perceived and organized space tries to penetrate into it. It is the place of emotional needs and reactions such as dream, desire, hope, security and fear. It is formed in the space of representations (lived spaces) through the images and symbols that accompany the real material space. This is the place for those who use it and those who live there. These spaces are used by these people and they are under intervention (Lefebvre 2014). It is the concrete space of the daily actions of the users; it is the space of the subjects, not the accounts (Lefebvre 2015).

\section{Spatial practices (perceived space)}

They construct everyday reality through routes, networks and patterns. There is a tripartite determination rather than the accumulation between the designed and the lived. Spatial practices control the relationship between these two spaces. Spatial practice covers "specific spaces and spatial clusters unique to any social formation that ensures continuity in a relative commitment to production and reproduction" (Lefebvre 2015). Spatial practice is primarily related to space, which is a material reality. It covers roads and networks that connect buildings, structures, workplaces, private spaces and leisure areas, so it is "empirically observed" (Lefebvre, 2014). Spatial practice also covers the production and reproduction processes of the physically structured environment so it is related to the practices of planning and relevant disciplines, and spatial practice is closely related to the conceived space through this. Because of its own qualities, that is, being related to physical space, this is also the perceived space because spatial practices provide direct experience of space. That is why Lefebvre also defines spatial practice as perceived space. Because of these qualities, spatial practices are identified, described, analysed at various levels such as "architecture, urbanism, arrangement of tracks and places (land), everyday life and, of course, city reality" (Lefebvre 2014).

Lefebvre interprets the formation of the space based on the results of three different processes. Lefebvre's trialectic space approach has been discussed in the context of "perceived-conceived-lived" space in three different processes. What explanations related to Lefebvre's efforts to understand the spaces in a multi-directional and holistic way indicate is to interpret all the discourses and distinctions related to that place together? According to Lefebvre (2015), in the study related to these discourses, which are physical, mental and social spaces, sub-concepts were created to define the city square that became a part of the city. These concepts have been identified as "physical square, experiential square and public square" and they are associated with Lefebvre's spatial triad approach theories and transferred to the concept map (Fig. 3).

- Lived space, space of representations-experiential square

- Perceived space, spatial practices-physical square

- Conceived space, representations of space-public square

- Experiential Square, "space of representations-lived space" relationship was established by the effect of daily life on space and the joining of these life gains. By deciphering and experiencing the square, the squarefocused practice is discovered. The experiential square is associated with the mental space, that is, the abstract and conceptual space. Spatial practices are supported by everyday formations, which are the arena of social life.

- The physical square "spatial practices - perceived space" relationship is based on the argument that the physical square can be expressed with the concept of energy and who tells the square is what is going on in it. The physical square is considered as the space which is directly in the life and manages our practical acquisitions. As stated by Tekeli (2018), physical spaces (squares) are places that shape loyalty, sense of responsibility, purpose of life, and especially people with weak economic conditions are getting more and more in need of space. The reality of what is happening in the square is also related to time and the space of representation has turned into a living and speaking square.

- The public square "representations of space-conceived space" relationship is based on how the government handles space and how the space is represented politically and scientifically. Therefore, the representation of the space allows the square to be perceived and constructed

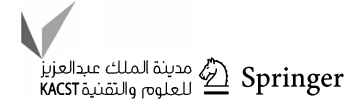


Fig. 3 The components of square perception and their relationship with Lefebvre's trialectic space concepts

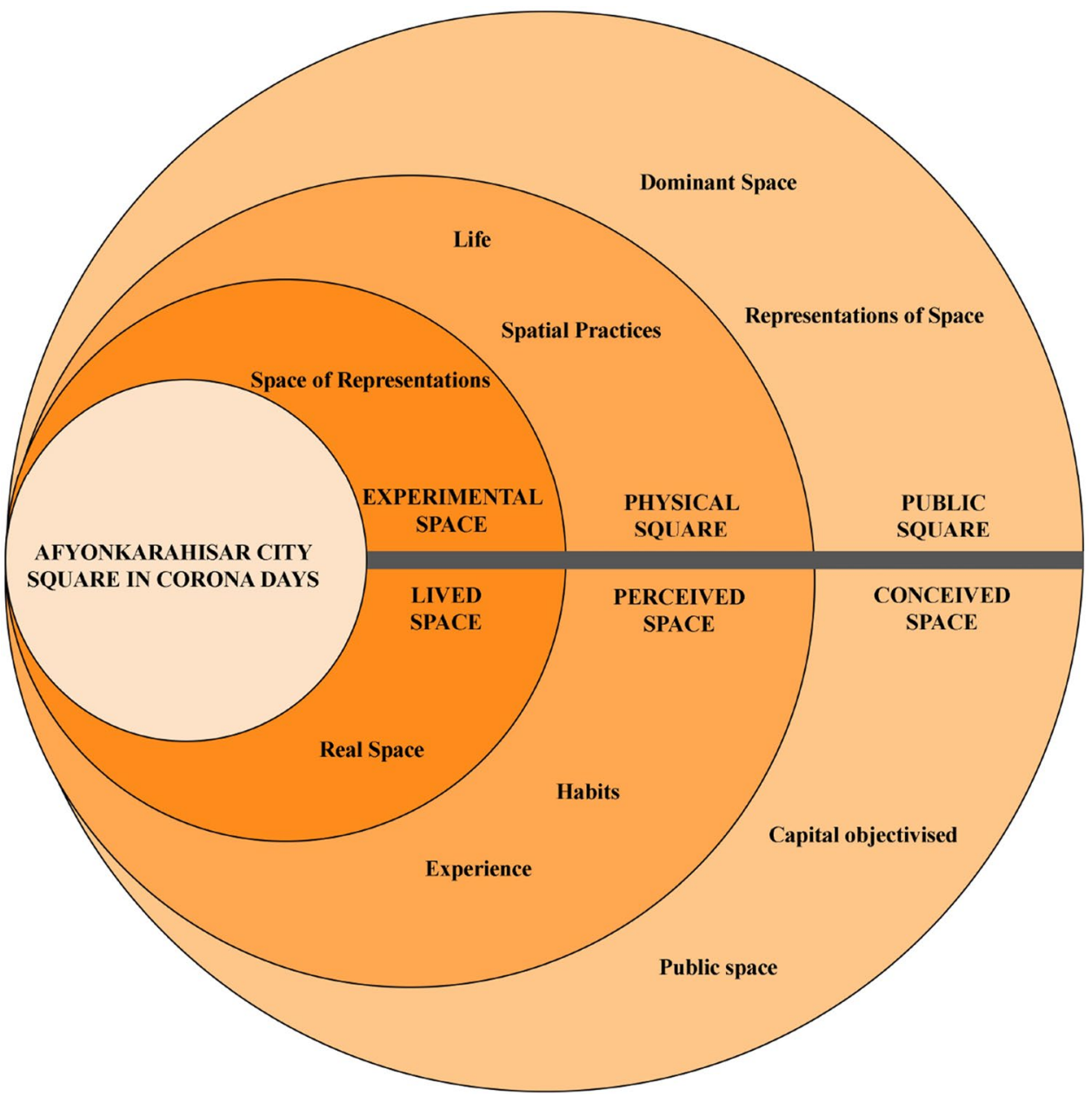

with order, information and codes. It is not interested in how the actual users of the space experience the space or how they live. This conceived space, which Lefevbre has conceptualized as the representations of space, has been described as "scientists, planners, urbanists, 'decomposing' and 'organizing' technocrats' associating the life and perception with the conceived," and in this context, the square has been handled from a public framework and associated with the social space; that is, the contradicting and liberating space. If there is pressure from those who are strong or a power that manifests itself as institutions and thoughts, then there must be information that serves the power on the one hand, and on the other hand there must be information that opposes and negates it. Space currently is the knowledge specific to the mode of production and action (Lefebvre 2014). In this argument, the essence of the public square is how it serves and how hegemony uses it as Onat (2013) stated.

The theoretical approach of Lefebvre has been associated with "experiential square-physical square-public square" perception of the city square, which constitutes the core of this study, within the context of concept map and analysed during the corona days (on the dates when important decisions were taken by the government) with city square experiences.

\section{Experiencing Afyonkarahisar city square through the trialectic space approach during the corona days: findings}

In the middle of the modern city and the rapid urbanization process, the only place where we can fully capture this essential feature of space is daily life. As in the common understanding of everyday life, it is not the area for storage, classification or arrangement and formatting according to the meaning and value system. As a result, what Lefebvre desires to reach through the production of space is not the production of general or any discourse on the space. He tries to explain the spirit of the place, its historical and social formation, in its effective production (Lefebvre 2015).

As Merrifield (2013) stated, the theoretical approaches stated in the concept map were analysed in the context of 
experiencing and reading Afyonkarahisar City Square during the corona days according to the processes related to not resolving the things in the space, but the things that come out as a space. Traces followed related to the analysis:

- Obtaining data in the context of the importance, practices, functions and layers of Afyonkarahisar city square in the historical process. Afyonkarahisar city square, which has undergone many changes in the historical process. The square and its surroundings took its final form which lasted until 2010. In 2010, it was decided to open a project competition for the reorganization of the city square and its surroundings. In line with these decisions, the square has taken its present form. Today, in the square, which has started to be used with the name of "Victory City Square", there are seating elements and food and beverage areas for recreation and gathering functions, empty spaces suitable for arrangement for social activities, cultural events and exhibitions, multistorey car parks and stairs to facilitate easy access to the car parks under the square. Victory (Zafer) city square performed very important social functions and witnessed important events of the period by creating different layers over time (Uyan 1999) (Fig. 4).

- Data obtained from the analysis of social and economic changes that occurred in cities as a result of the coronavirus, which emerged in Wuhan, China in December causing a disease called "Covid-19", spread to all continents except Antarctica. The first corona virus case was detected on March 11 in Turkey. World Health Organization (WHO) named the disease caused by the corona virus as "Covid-19" on February 11. Later, it was declared as "pandemic", which means global epidemic (Url 1)

In all countries that have been struggling with the coronavirus outbreak for about five months, the decisions taken by the state in a social, political, cultural, economic and social context have had a significant impact on cities and, therefore, city users and communities. In this process, which was declared as quarantine days in many countries, people were asked to break their relationships with places, they were expected to isolate themselves, and, therefore, soulfree urban spaces emerged as a result of these prohibitions.

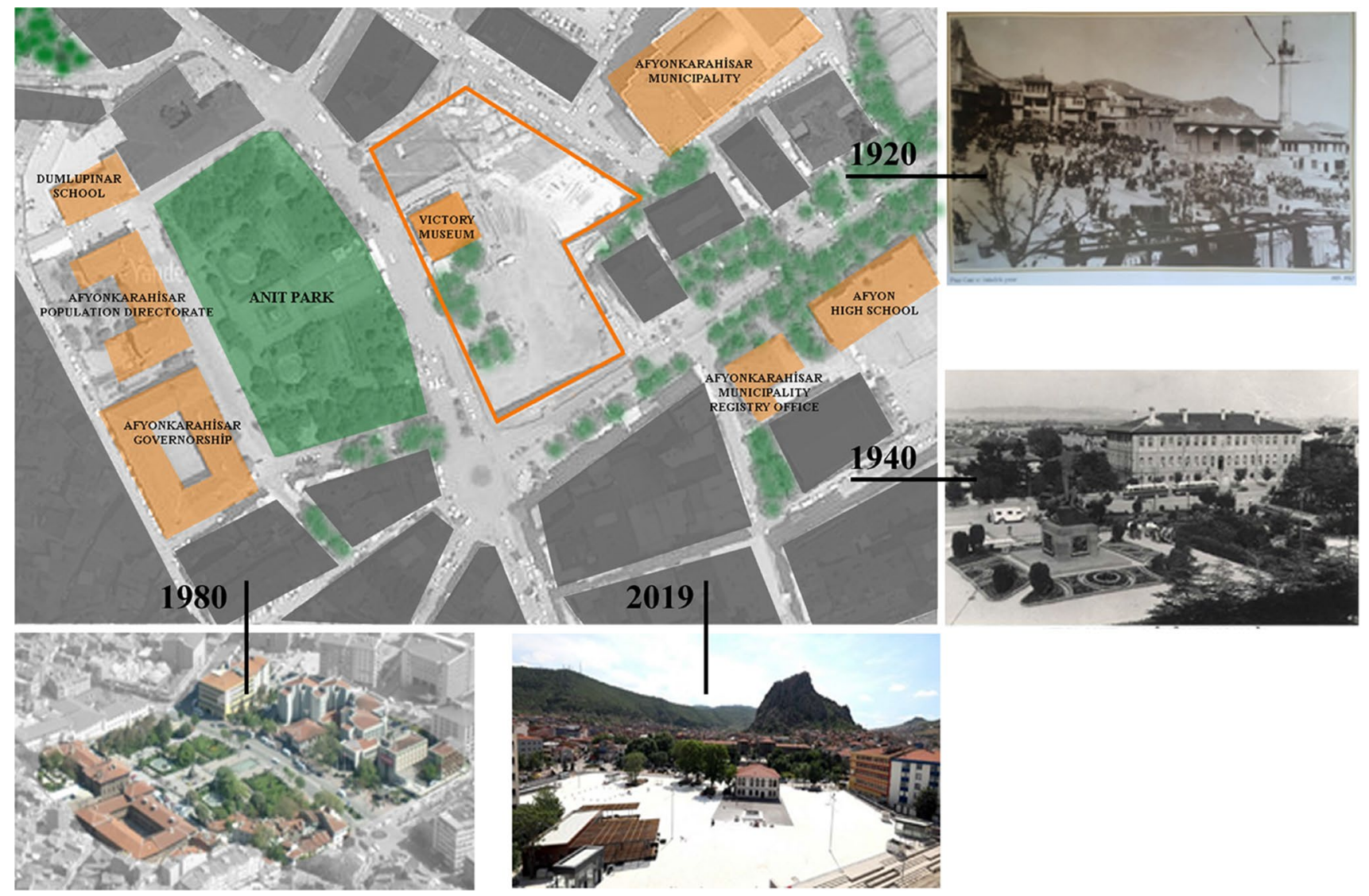

Fig. 4 Historical process of Afyonkarahisar city square 
- When the corona virus which was declared as a pandemic was seen in our country, the country management and local governments have taken serious decisions and imposed sanctions to protect the social distance and not to cause chaos in this painful process. In cities, the effective use of urban spaces (open-closed) is reduced to a minimum level and urban residents are prohibited from using open urban spaces. The follow-up of this process throughout our country is carried out through social media or television. However, the scope of the study was limited to the city scale of Afyonkarahisar. It is expected that the spatial and behavioural analysis regarding Afyonkarahisar city square, which is a section of the city scale, will give clues about the dynamics of the city of Afyonkarahisar during the corona days. The data obtained on dates following the days when the measurements and decisions taken by the state were officially declared to the public between 12.00 and 14.00 which are times when the usage density of the city square can be perceived regarding the developing and changing process in the city square of Afyonkarahisar during the corona days and the numerical data received from Afyonkarahisar Municipality on the human population of the square.

March 8, 2020-International Women's Day and spatial practice of Afyonkarahisar city square.

March 11, 2020-The day when the first corona virus case was seen in Turkey and spatial practice of Afyonkarahisar city square.

March 17, 2020-The day when the outdoor activities in public places, entertainment and recreational areas were prohibited by the government in Turkey and spatial practice of Afyonkarahisar city square.

March 23, 2020-The day when the ban on going out for people who are over 65 or have chronic diseases was declared and spatial practice of Afyonkarahisar city square.

April 4, 2020-The day when the ban on going out for people who are under 20 was declared and spatial practice of Afyonkarahisar city square.

- Data obtained from the establishment of the relationship between the basic moments of Lefebvre's trialectic spatial approach and the definitions determined for the city square of Afyonkarahisar.

Lived space, space of representations-(experiential square).

Perceived space, spatial practices-(physical square),

Conceived space, representations of space-(public square), in the context of relations; analysing the dynamics of the city square through the monitoring/observation model of the space with information systems and rereading the city square through the behavioural matches of the city subject that constantly criticizes the city space with spatial practices.

In his study on the conceptualization of space, Lefebvre reveals that space is produced socially. An assessment that will be made based on what a city space looks like, the city's organization and how the city's subjects experience it, how urban space and city subjects manage mutual communication provides us material basis for thinking about a series of possible emotions and the social practice of the subjects, evaluating and accessing them and the data obtained from Afyonkarahisar city square's experience criteria and traces on the corona days were associated with the theories of Lefebvre's trialectic spatial approach in the context of seeking answers to the question "How is it possible to open social life in space (city square)?".

Spatial and behavioural analyses of Afyonkarahisar city square were made during critical days and hours when measures and prohibitions were also applied in cities in line with the decisions taken by the government, and as a result of experiencing the space, the graph of the human population in the square is given below to read the dynamics of the square (Fig. 5).

The numerical data obtained from the graph, that is, the human population at the determined critical dates, has actually created a base for the behavioural and spatial analysis of the city square and based on this, Lefebvre's trialectic spatial moments are associated with the defined dynamics of the square (Tables 1, 2, 3, 4, 5).

\section{Findings}

When the coronavirus became a threat to be fought, a number of measures began to be taken by the government in Turkey. While measurements such as closing temporarily the schools and universities, respectively, across the country by the government, the banning of transportation to some countries, closing the public places for resting and entertainment, delaying the all kinds of meetings and activities that bring people together, closing the mosques, the postponement of

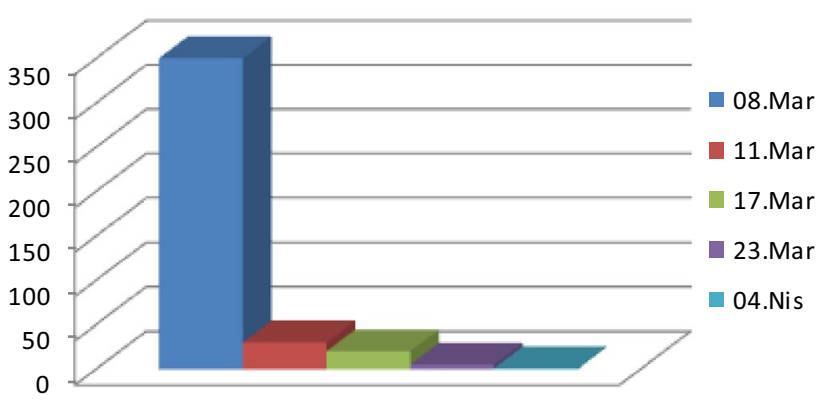

Fig. 5 The number of people according to dates 
Table 1 Analysis of the city square on March 8

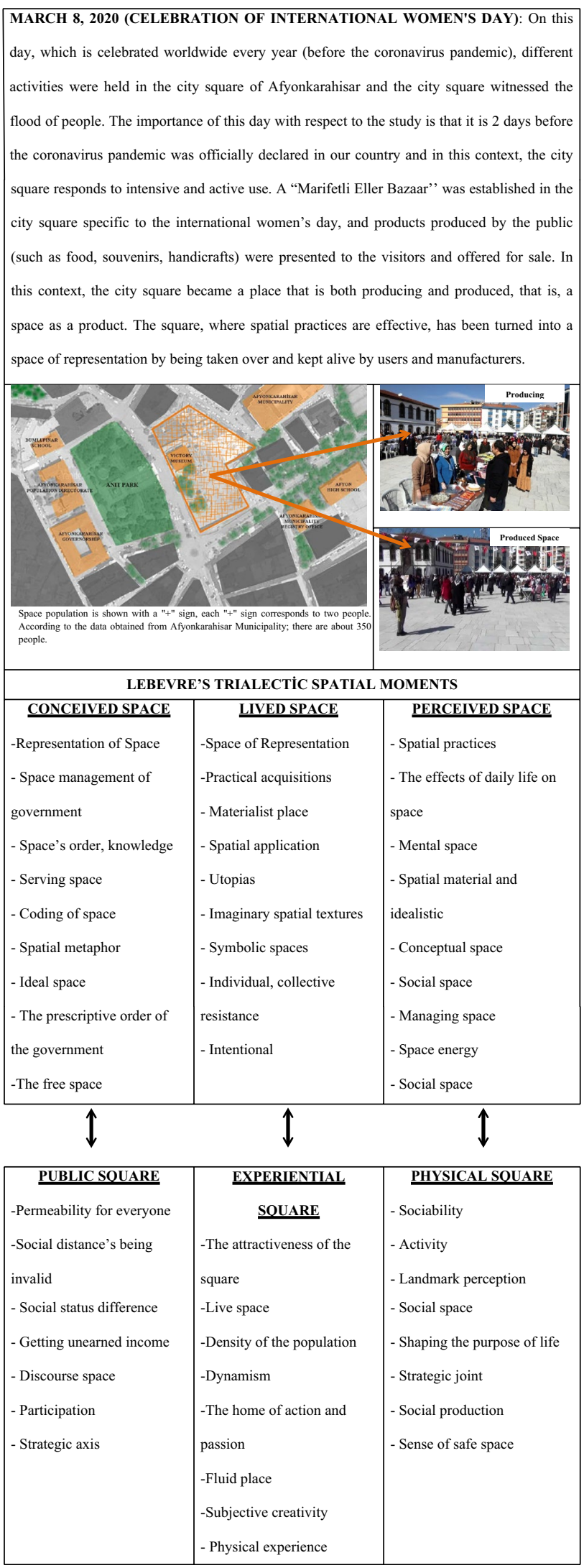

Table 2 Analysis of the city square on March 11

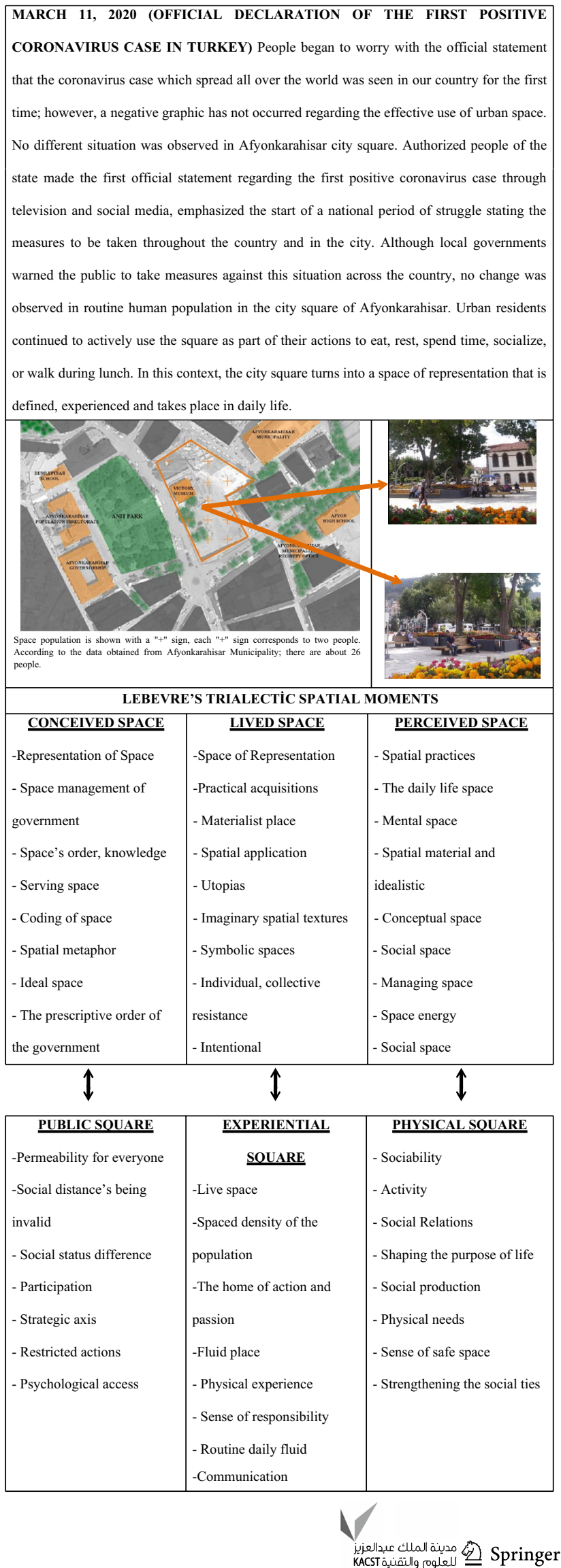


Table 3 Analysis of the city square on March 17

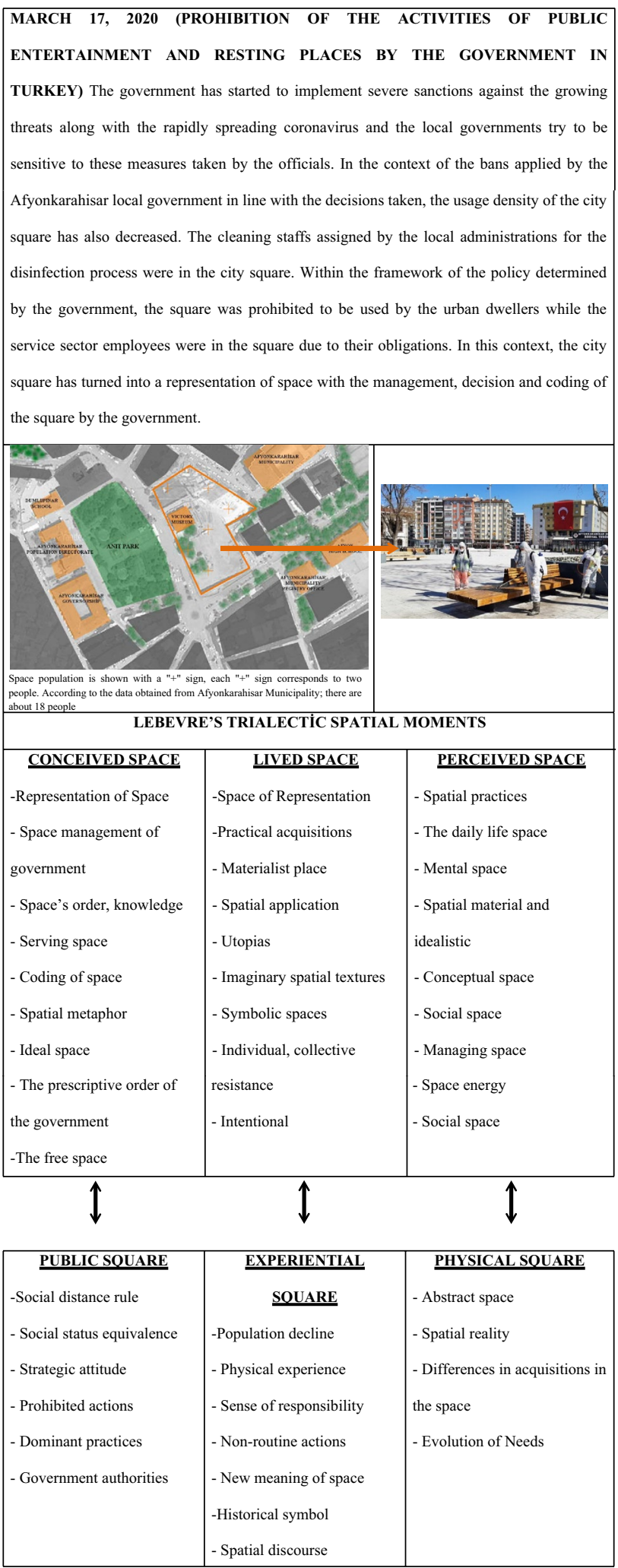

sports competitions, banning of going out for people who are over the age of 65, stopping the activities of all workplaces where there may be intense human population, prohibition
Table 4 Analysis of the city square on March 23

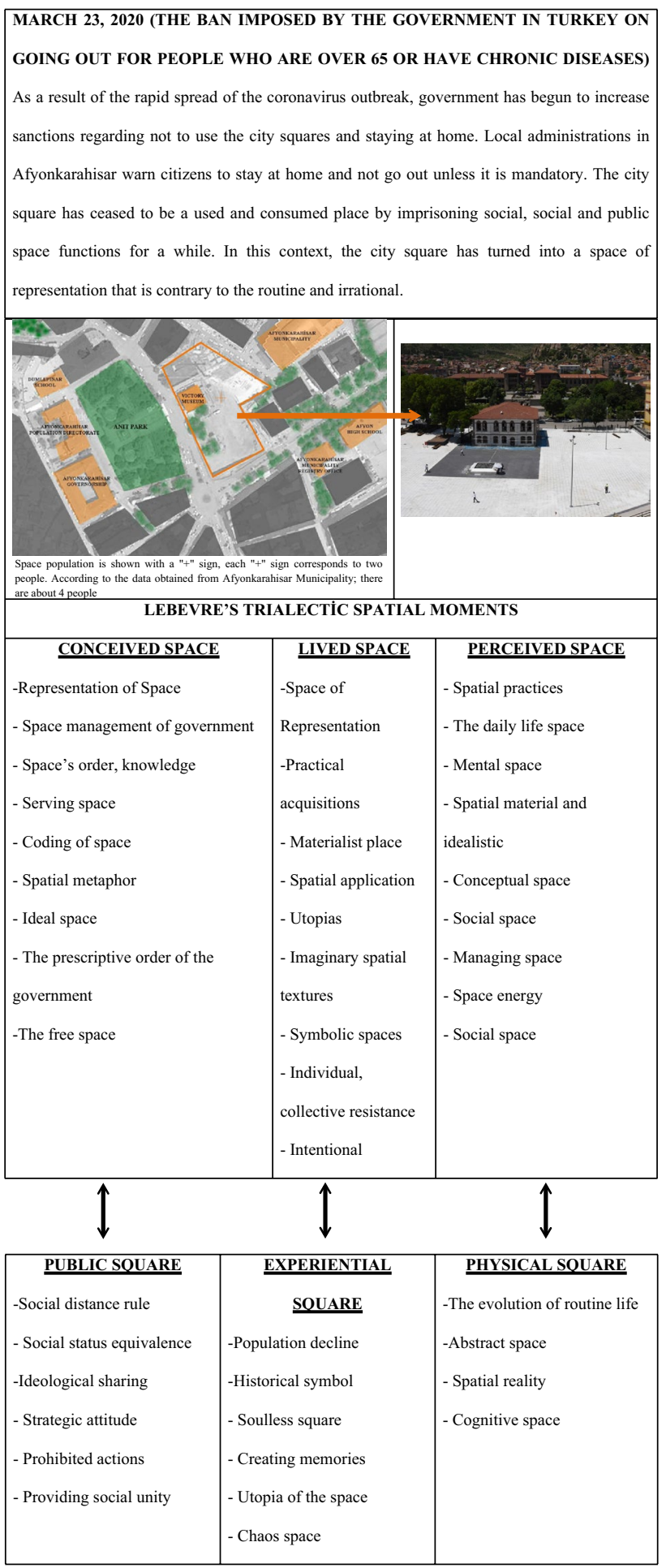

of intercity travel, prohibition of going out for people who are under the age of 20 , curfew in some cities limited to the weekend have been taken, sanctions have been applied by the local authorities in cities to combat the epidemic and make people to stay at their homes. People have been told to "stay home" by means of audio, visual and social media 
Table 5 Analysis of the city square on April 4

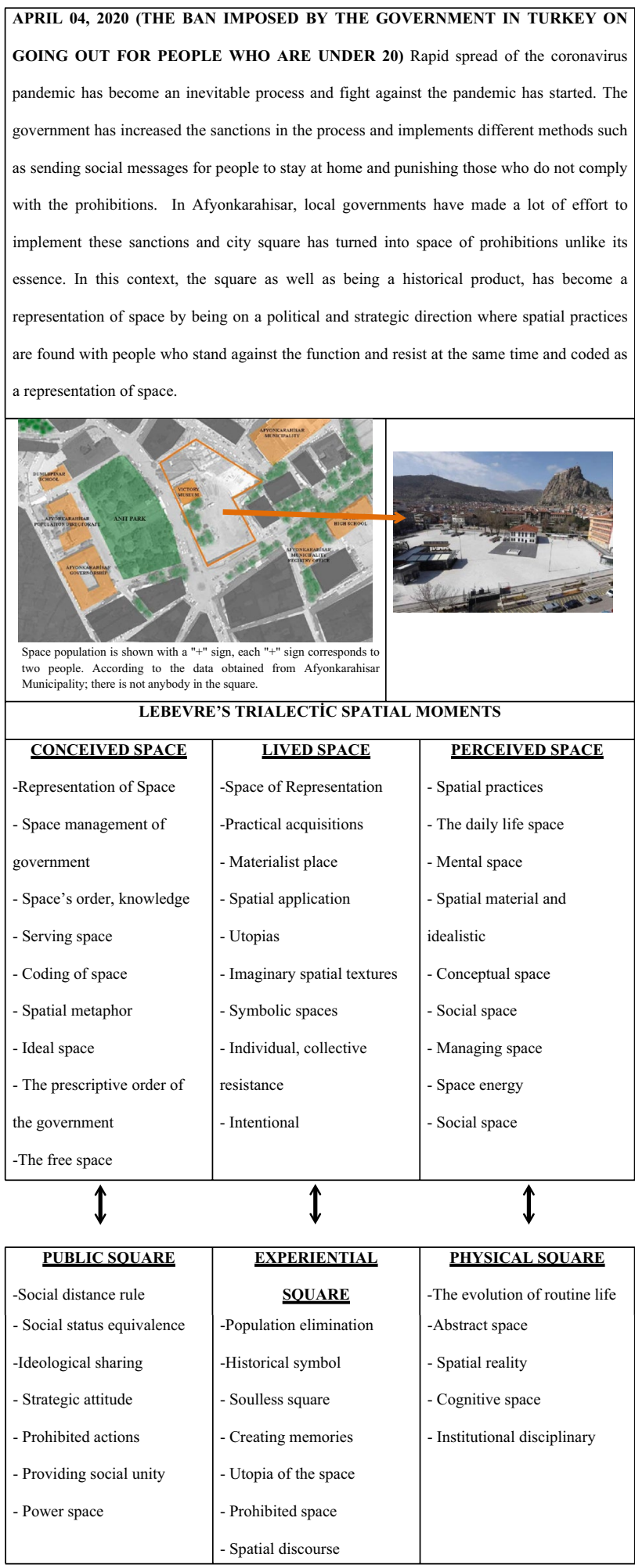

platforms. While social messages in the world and across the country have been transmitted to the audience through television screens, the perception for the use of urban spaces have been created through the human population in the city squares. Corona days are similarly experienced in the city of Afyonkarahisar. Urban dwellers have been explained that they should not go out onto the streets unless they have to and sanctions have been applied to make them stay at home and the government has restricted the use of the urban spaces which are fluid, dynamic, active and build relationships with the environment and have relations of production. Spatial and behavioural practices regarding the Afyonkarahisar city square were analysed by numerical data obtained from Afyonkarahisar Municipality related to the human population of the square on important dates when measurements were taken by the government and sanctions were applied. The findings obtained as a result of the analysis are as follows:

The space experienced on March 08, 2020 between 12.00 and 14.00:

While "8 March" is celebrated every year as "International Women's Day" in all countries, celebrations are also held in our country. Activities for this special day were organized in the city of Afyonkarahisar. An event to which people intensely attended was organized in the city square, which is a dynamic and fluid urban space where people have easy access. Since this day correspondences a date before the official declaration that the coronavirus pandemic was seen in our country, production relations, social production, social life, urban dynamics continue in a routine way, In this context, the city square which was space of representation with the activities organized, understanding of produced and producing space where that the spatial practices are realized and its users exist and it was seen that it turned into Baudrillard (2011), representation of space with a materialist approach, located in a strategic joint and of which space organization was coded by the government at the same time on the axis of Lefebvre's trialectic spatial moment. It has been observed that users could realize their physical experiences and actions in the square with its feature of being live, dynamic and fluid space and where there is a dense population and as a result of this behavioural analysis, it has been concluded that spatial dynamics in the city square respond to the directional, practical acquisitions that constitute the definition of "lived place" in Lefebvre and they build relationship with the materialist components. On this day, when the social distance has not yet been realized, social status difference and discourse space have been observed by coding that the users who conduct their commercial activities in the city square have low economic level and as a result of this behavioural analysis, it has been concluded that the spatial dynamics in the city square build relationship with the components such as establishing the order of the space by the government and serving space that constitute the definition of Lefebvre's "conceived space". As a result of observing the city square as a place where there is social production, activities, and creating a landmark perception, it has been concluded that the spatial dynamics in the city square

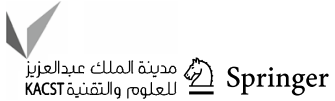


establish relationship with the components of being social space that accepts the effects of daily life on the space that constitute the definition of Lefebvre's "perceived space".

The space experienced on March 11, 2020 between 12.00 and 14.00:

On March 11, 2020 when it was officially declared that the first positive coronavirus case was seen in Turkey, there has not been a change in routine city life. With the official start of the fight against pandemics in our country, the process of taking measures of the government also began. Following the 8th of March 'International Women's Day' activities, Afyonkarahisar city square, which has multiple identities, has taken on a different function with the instantaneous population decrease and orientation effect. Indeed, the acquired space has gained its essence again. In this context, it was observed that Afyonkarahisar city square at this date was alive, fluid and living space, a communication space, it could respond to different actions, and physical experiences have been realized and as a result of these behavioural analyses, it has been concluded that the spatial dynamics in the city square relate to the practical acquisitions that make up the Lefebvre's "lived space"; that is, "Space of Representations" approach, and symbolic space perception for users. It has been observed social status differences are valid in the sense that that the city square is only an intermediate space used by some people as a passageway, just an instant space used by some people as a meeting place and a fixed space used by some people as a place to spend time. it has also been observed that actions are limited and it is a participatory space. As a result of the experience, it has been concluded that the spatial dynamics of the city square relate to the components of being arranged by the government, coded and serving space which constitute the "conceived space" definition of Lefebvre. On this date, it has been observed that daily activities take place in the city square, social relations are established, social production is provided and with this spatial practice, the spatial dynamics of the city square relate to Lefebvre's "perceived space", that is, "spatial practices" which are defined as a social and conceptual space and become the daily life practice.

The space experienced on March 17, 2020 between 12.00 and 14.00:

March 17, 2020 when the activities of public resting and entertainment places were stopped by the government is one of the dates on which a serious perception of the importance of the fight against coronavirus has been created. In this context, in the observation made on March 17, 2020 in the city square of Afyonkarahisar, it was found that the population decreased considerably, the square was used for actions outside of the routine, a new meaning was placed on the square leaving a historical mark. Regarding this experience; it has been concluded that the spatial dynamics of the city square relate to the components such as the existence of spatial applications that make up Lefebvre's "lived space" approach, coding symbolic spaces and displaying individual attitudes. In this date, in line with the measures taken by the government in the city square, it was clearly observed that the social equality in terms of restricting the usage of city for everyone square without looking at the social status of the urban dwellers was seen, the social distance rule was obeyed, the actions were banned the actions of the government authority were clearly observed, as a result of this experience, it has been concluded that the spatial dynamics of the city square establish a relationship with the components that form the "conceived space", that is, "representations of space" approach, such as producing an order on the space, creating codes and creating the ideal space by the government. At this date, it has been observed that the city square has turned into an abstract space in the context of changing routine life, actions such as disinfection occur in the square and the needs for the square have differentiated and as a result of this experience, it has been observed that spatial dynamics in the city square relate to components such as mental space, conceptual space and ideal space that constitute Lefebvre's "perceived space" approach.

The space experienced on March 23, 2020 between 12.00 and 14.00 .

The day when curfew was imposed for people who are over 65 and have chronic diseases by the government in Turkey, Afyonkarahisar city square which is one of the city spaces that forms the arena of social life faced with this ban. It has been observed that the human population in the city square has decreased considerably, but some elderly people who use the square effectively continue to use the seating areas in the square by resisting the ban and the square has become symbolic since they have not been able to live the space. On that day, it has been also observed that the city square has not been used effectively, left historical marks, turned into a soulless space with accumulated memories and there is the possibility of turning into chaos space if the rules are not obeyed and as a result of this experience, it has been concluded that the spatial dynamics of the city square relate to the components such as utopia space, symbolic space, individual resistance which constitute Lefebvre's "lived space" and "space of representations" approach. The city square was read as the dictation of the social distance rule, social status equality, forbidden actions and the ideological sharing and as a result of this reading, it has been concluded that the dynamics of the city square are associated with components such as the order of the space, coding, ruling order of the government which constitute the Lefebvre's "conceived space" approach. Findings such as the end of the routine life cycle in the city square, meaningful and concrete city square's becoming an abstract space that no longer allows flexing and transforming into a cognitive space have been matched with expressions such as the mental space, 
conceptual space, the governing space that form the "perceived space" approach of Lefebvre.

The space experienced on April 04, 2020 between 12.00 and 14.00:

The day when curfew was imposed for people who are over 65 by the government in Turkey, producing and living space turned into entirely abstract space with other diachronic prohibitions imposed and it has been seen that there are no words to speak in this square which has been established as government space. At this date, it has been observed that discourse rather than spatial actions existed in Afyonkarahisar city square, the space where memories were accumulated turned into a memory itself, evolved into an organism that could not live and have a spirit, ideological attitude was exhibited, the routine was interrupted with prohibited actions, individual resistance was present despite the prohibitions and the government displayed a strategic attitude. As a result of this space experience, the practical acquisitions that make up Lefebvre's "lived space", "conceived space" and "perceived space" approach have been matched with elements such as symbolic spaces, serving space, spatial metaphor, mental space, conceptual space and governing space. In this context, the space representations that exist in the city square of Afyonkarahisar have enabled actions, life and the definition of the experienced space and associated with the space of representation. The city square has turned into a space of representation by enabling new acquisitions, meanings, imaginary spaces, allowing resistance against dominant practices and developing an attitude towards space practices. The city square has become a part of spatial practices and transformed into its reality with the restriction of the usual process of daily life, providing new life gains, creating or destroying the meaningful relationship that it has established with the environment.

\section{Conclusion}

The fight against coronavirus continues intensely all over the world, in our country and in cities, and this pandemic process has negatively affected the countries; hence, the cities with respect to social, cultural, economic, physical and psychological context. In the corona days during which the city dynamics have changed, the decisions and the measures taken regarding the use of urban spaces directly intervened in the way of life of the people. While the urban space-oriented practices and course of the corona days were conveyed to the audience through the media as the product of the intervention, city square images defined as the heart of the city were used on television screens at first which shows that the population in the city squares is a clue to understanding the dynamics of the city. In this context, it has been concluded that the spatial and behavioural analyses made regarding the city square of Afyonkarahisar contain clues about the dynamics of the urban spaces during the corona days. The fact that the city square is a lively space pattern that changes form, changes, flows, develop, shapes life, organizes, resists, produces or produced lead the study to associate with Lefebvre's trialectic spatial moments to analyse the spatial codes that are the means of living, understanding and producing in the city square. As a result of associating the dynamics defined for Afyonkarahisar city square with Lefebvre's trialectic spatial approach theories that aim to see all the discourses and distinctions related to the space, it has been concluded that the city squares are not just a language, they do not have only materiality but they are also a practice, experience at the same time; it is possible to make sense of spatial, social relations and processes in a holistic framework if the subject experiences the square, city squares are the tools to understand the authoritarian order or irregularity of political power, city squares with political functions are a strategic joint for the governments, the square considered as the product is the basis of economic and social relations and finally the city square is a multi-layered space which reflects the life profile, has a flexible structure with multiple identities and which is collective and dominant with a common will.

Funding This study was self-funded.

\section{Declarations}

Conflict of interest There are no conflicts of interest.

\section{References}

Akpınar Yİ, Gümüş K (2012) Taksim yesterday-today: an ideological reading. TMMOB Chamber Architects 28:38-46

Alexander C (1977) A pattern language. Oxford University Press, New York

Baudrillard J (2011) System of objects. Boğaziçi University Press, İstanbul

Çaçtaş M (2016) Examination of city squares in terms of their functionality: Izmir example, (Master Thesis). Bahçeşehir University, İstanbul

Calvino I (2016) Invisible cities. Remzi Press, İstanbul, pp 88-89

Deleuze G (2013) Foucault. Norgunk Press, İstanbul

Erdönmez ME, Akı A (2005) Effects of open public urban spaces on community relations. YTÜ Architect Faculty. e-J 1:67-87

Foucault M (2016) Michel Foucault. Of other spaces (1967) Heterotopias, Architecture/Mouvement/Continuité, 10. https://doi.org/ $10.2307 / 464648$.

Gülhan ST (2013) The geography of freedom: an analysis of the trialectic praxis of spatial and the search for integrity. Mülkiye J 37(1):31-69

Harvey D (2013) Rebel cities. Metis Press, İstanbul

Keleş R (2012) Public space urbanization and awareness of urbanism. Güney Architect J 15(2):10-12

Lefebvre H (2014) Critique of Everyday Life. Foundations for a sociology of the everyday, (Translate John M). Verso, London

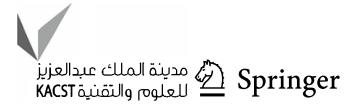


Lefebvre H (2015) The production of space (Translate I. Ergüden). Sel Yay, İstanbul

Lynch K (2016) Lynch K (2016) The 1mage of city (Translate İ. Başaran). Turkey İş Bank Press, İstanbul

Marcus CC, Francis C (1998) People places. Design guidelines for urban open space. Van Nostrand Reinhold Company, New York

Merrifield A (2013) Henri Lefebvre: a socialist in space. In: Crang M, ve Thrift $\mathrm{N}$ (eds) Thinking space. Routledge, London

Moughtin C (2003) Urban design. Street and square. Butterworth Architecture, Oxford

Mumford L (2013) The city through history: origins, transformations and future. Ayrıntı Press, İstanbul

Onat N (2013) Public space and its boundaries, approaches by Hannah Arendt and Jürgen Habermas. International Akım Identification Press, İstanbul

Özkan MB, Küçükerbaş EV, Kaplan A, Hepcan Ş, Malkoç YE, Sönmez H (2003) Master plan work in the context of Muğla city public outdoor spaces. Ege University Press, İzmir, pp 10-11

Pol E (2002) The theoretical background of the city-identity-sustainability network. Environ Behav. https://doi.org/10.1177/00139 16502034001002

Schmid C (2008) Henri Lefebvre's theory of the production of space: towards a three-dimensional dialectic. In: Kanishka G, Richard
M, Christian S, Stefan K (eds) Space, Difference, everyday life: reading Henri Lefebvre. Routledge, New York, pp 27-45

Soja EW (1996) Thirdspace: journeys to Los Angeles and other Realand-lmagined places. Blackwell, Oxford

Stanek L (2011) Henri Lefebvre on space: architecture, urban research, and the production of theory. University of Minnesota Press, Minneapolis

Stanek L (2012) Architecture as space, again? Notes on the spatial turn. Le J Spec 4:48-53

Stanek L (2014) Architecture as Space, Again?. http://www.academia. edu/4714722/Architecture_as_Space_Again_Notes_on_the_Spati al_Turn. Accessed 15 Mar 2020

Stavrides S (2016) Urban heterotopia. Sel Press, İstanbul

Stavrides S (2018) Common place: the city as commoners. Sel Press, İstanbul

Tekeli İ (2018) Politics as modernity is overcome. İmge Press, Ankara

The Ministry of Health (2020) The first corona virus case in Turkey. https://www.bbc.com/turkce/haberler-dunya-51177538. Accessed 15 Mar 2020

Tschumi B (1996) Architecture and disjunction. MIT Press, Cambridge Uyan M (1999) Afyonkarahisar in memories. Afyon Kocaetepe University Press, Afyonkarahisar 